\title{
Promises and limits of community-based organizations in bridging mismatches of scale: a case study on collaborative governance on federal lands
}

$\underline{\text { Jean Lee }}^{1}$ and $\underline{\text { Jacopo Baggio }}^{2,3}$

\begin{abstract}
Federal land managers in the United States are tasked with managing a vast array of resources for current and future generations. However, coordinating action among multiple stakeholders across diverse landscapes is challenging given that the organizations and institutions set up to govern federal lands are often unable to overcome scale-related challenges. Unconventional oil and gas development is often a contentious issue on federal lands. Identifying how to bridge scale mismatches in this sector is critical for achieving management objectives. To gain a deeper understanding of the institutional landscape governing oil and gas, we took an in-depth case study approach and examined a case in the western United States where communities worked with federal land managers to cancel 25 existing oil and gas leases. We identified the most relevant scale mismatches pertaining to unconventional oil and gas development and assessed the role of community-based organizations in bridging scale mismatches to increase institutional fit. Our results demonstrate the importance of community-based organizations that can function as bridging organizations to engage a broad set of actors across scales. Our results also highlight the importance of creating shared visions across diverse stakeholder groups to foster collaboration. We conclude that overcoming scale mismatches requires a focus on shared values and the creation and maintenance of flexible governance networks.
\end{abstract}

Key Words: bridging organizations; community-based organizations; federal land management; governance; scalar mismatches; unconventional oil and gas development

\section{INTRODUCTION}

In the western United States (U.S.), lands directly managed by the U.S. federal government (federal lands) comprise $46 \%$ of the total land available and are key areas for future well-being (Charnley et al. 2008, Congressional Research Service 2020). Land managers are challenged by multi-use management goals, combined with the mandate to manage resources for current as well as future generations. Further, the resources at stake span multiple political jurisdictions and are interdependent with landscapes that are not necessarily under the authority of the federal government (e.g., private landowners, municipalities, counties, state authorities).

Unconventional oil and gas development occurs on federal lands and threatens the resiliency of the federal landscape, with documented adverse impacts on wildlife and water quality, as well as uneven economic impacts (Clark et al. 2012). Those impacts pose several challenges for the U.S. Forest Service, the oldest and second largest federal land management agency tasked with managing for multiple uses in a way that "will best meet the needs of the American people" (U.S. Congress 1996). Unconventional oil and gas development on federal lands highlights how the difference between the extent of ecological processes and the political jurisdiction that has the authority to shape and change such processes can lead to a lack of fit between the institutions and the resources. This lack of fit creates scale mismatches, which compromise the social and ecological resiliency of the landscape upon which millions depend (Young 2002, Galaz et al. 2008, Epstein et al. 2015). For example, with respect to forest management, wildfires or invasive species outbreaks do not respect jurisdictional boundaries, and hence require coordination and collaboration across multiple administrative units (Fischer 2018). With respect to unconventional oil and gas development, negative effects on the environment may "flow" through rivers and aquifers, potentially affecting individuals and communities that do not receive economic benefits from unconventional oil and gas development or that were not involved with the actual decision-making process (Solis et al. 2017).

Effective environmental governance requires a reasonable fit between institutional arrangements, ecological processes, and social systems (Lebel et al. 2013). Institutions that take into account varying temporal and spatial scales will be able to more effectively govern the natural resources at stake (Folke et al. 2007, Lebel et al. 2013). Yet, achieving this fit is difficult when multiple stakeholders are involved. Collaborative governance has been proposed as a way to increase the ability to achieve institutional fit; overcome spatial, temporal, and scope mismatches; and foster more resilient social-ecological systems (Folke 2006, Armitage et al. 2008). Studies on wildfire policy, wildlife management, watershed initiatives, and collaborative forest planning processes highlight that collaboration between different political jurisdictions and private and public entities, together with longterm planning, can reduce the adverse effects of scale mismatches (Schoon and York 2011, York and Schoon 2011, Bodin and Nohrstedt 2016, Ager et al. 2017, Sayles and Baggio 2017).

Even though drilling for oil and gas is a significant form of land use on federal lands, few scholars have examined the nature of scale mismatches in the oil and gas industry and the extent to which collaborative governance can reduce the extent of those 
mismatches and increase institutional fit. Understanding the institutional landscape governing oil and gas, as well as the actors who shape and interact with those institutions, is vital for fostering more resilient and adaptive systems.

Our empirical research identifies the mismatches that are most relevant to oil and gas on federal lands and identifies ways that key actors and organizations have tried to minimize the mismatches and foster collaborative governance to maximize institutional fit. We focus our study on the western region of Colorado, USA, where the diversity of stakeholders and institutions revolving around the oil and gas industry creates barriers to collaboration. The empirical work presented here showcases how communities and stakeholders worked together to change the outcome of 25 oil and gas leases in the White River National Forest in Colorado. We highlight the mismatches and the process by which local organizations were able to bridge mismatches and pressure the Forest Supervisor to close an area to oil and gas leasing. Albeit centered in western Colorado, our results are highly relevant to other regions given the ongoing and nationwide conflict among different stakeholders on federal lands.

\section{SCALAR PROPERTIES AND INSTITUTIONAL FIT: AN OVERVIEW OF CONCEPTS IN RELATION TO FEDERAL LANDS}

Scale mismatches and institutional fit have received heightened attention in the literature on environmental governance and social-ecological systems. Overcoming scale mismatches and increasing institutional fit are considered key factors in effective environmental governance (Lebel et al. 2013, Epstein et al. 2015). Scale can be conceptualized as the analytical dimension that one adopts to study a particular phenomenon (Gibson et al. 2000, Cash et al. 2006). Different "levels" exist within each scale and serve as a particular unit of analysis. For example, local and global levels are different units of analysis within the spatial scale dimension (e.g., local to global); slower (e.g., days, seasons) and longer (annual, decades) time frames are different units of analysis within the temporal scale dimensions.

Effective institutions will take into account interactions across scales. However, the institutions set up to govern federal lands are often unable to overcome scale-related challenges and the multiple cross-scale interactions inherent in managing ecosystems (Schultz et al. 2019). Scale mismatches occur when scales of management do not line up with spatial, temporal, or functional scales (Cumming et al. 2006). For example, effective strategies to address wildfire risk need to be decided at a regional level, yet actions to address wildfire are often taken at a local level, which does not always result in reduced wildfire risk (North et al. 2012, as cited in Schultz et al. 2019). Further, forest management plans that dictate how forest resources should be used are supposed to be revised every 10 years, yet revisions often take lengthy periods of time and are unable to adapt quickly enough to accommodate those changes (Fischer 2018). Further, the plans designed to manage those natural resources often extend beyond the boundaries of the forest itself and require coordination with other actors. Spatial mismatches also exist because the U.S. Forest Service manages large areas of land, yet the landscape spans counties that prioritize the use of federal lands differently. Forest Supervisors have a difficult time ensuring that their decisions will accurately reflect the interests and values of the different communities and stakeholders whose well-being depends directly or indirectly on the services that forests provide.

In addition to paying attention to scale and cross-scale interactions, institutions set up to govern social-ecological systems should align with ecosystem processes and reflect the interests and values of the communities. This alignment, also known as "institutional fit," is important in effective environmental governance (Lebel et al. 2013). Institutional fit is dependent on a variety of factors, such as attention to spatial and temporal scales as well as whether or not people are able to participate in the creation of institutions that manage the natural resource (Epstein et al. 2015) and whether institutions can adapt to changing local conditions. However, achieving institutional fit is difficult when ecological processes and social norms and values vary across spatial and temporal scales. For example, institutional arrangements that govern forest management are set at a forest level and are driven by federal mandates in the United States, yet those forested areas span several different counties that have populations with varying interests. Even though Forest Plans are unique to each forest, and Forest Supervisors are allowed discretion over some elements of land management (e.g., where to allow grazing or drilling), they are still required to follow federal guidelines (e.g., management decisions cannot conflict with the Endangered Species Act and Clean Water Act), which may limit their ability to make decisions that reflect the desires of the local community. Further, institutions set up to manage federal lands are usually long-lasting and relatively durable, yet demographics of rural towns in the American West have changed, and continue to change, rapidly (Abrams et al. 2015). While those institutions and organizations are set up to ensure that natural resources are managed for the benefit of the American public, managing for those objectives is inherently difficult given the size and scope of the management priorities and the multiple interests and stakeholders involved (e.g., wildlife and endangered species, motorized versus nonmotorized recreation, hunting and fishing) (Fischer 2018).

\section{BRIDGING ORGANIZATIONS AS CENTRAL ACTORS IN COLLABORATIVE GOVERNANCE}

The multiscalar properties in land management suggest that effective collaborative governance and building collaboration networks requires the presence of organizations that can act as bridging organizations to connect diverse actors at multiple scales (Cash and Moser 2000). Bridging organizations are commonly conceptualized as organizations that facilitate the coproduction and transfer of information from one actor of interest to another; they engage with stakeholders who have different objectives, values, and beliefs (Clark et al. 2016a, b). Recently, several scholars have discussed how community-based organizations function as bridging organizations to link actors across different scales (Molden et al. 2017). Bridging organizations can connect decision-makers and actors at different levels, share appropriate knowledge, or aid in building trust among different stakeholders (Cash and Moser 2000). In the context of federal land management, bridging organizations are often community-based organizations that work with federal agencies to achieve certain objectives (Abrams et al. 2015). While community-based organizations differ in size and capacity, they are increasingly recognized as influential actors in the rural American West, where 
they play a significant role in fostering place-based collaboration and influencing the ways forests and federal lands are managed (Wondolleck and Yaffee 2000, Wilson 2006, Cheng et al. 2015). These actors have played a range of roles, from facilitating multistakeholder collaborations to engaging in what has been called "institutional work," where they fill institutional voids and help with land management activities or community development work (Abrams et al. 2015). Community-based organizations have had varying degrees of success in reconciling community interests with federal management objectives. While some communitybased organizations struggle to gain traction in the community (Armitage 2005, Gruber 2010) and face obstacles such as funding or legitimacy, others have been relatively successful at reconciling local interests with broader federal land management directives by focusing on leveraging existing networks and filling in roles left behind by state or corporate actors (Abrams et al. 2015).

Research on community-based organizations in the rural West has been limited primarily to issues related to wildlife, timber, or fire (Schultz et al. 2019). Unconventional oil and gas development has received relatively little attention, despite the important role it plays in shaping land use and rural livelihoods. As unconventional oil and gas development becomes an increasingly contentious issue in the Intermountain West, analyzing and assessing how community-based organizations can minimize mismatches and mediate relationships among different actors at multiple scales will be important for effective environmental governance of federal lands.

\section{METHODS}

\section{Case study context}

Colorado is one of the top five natural gas producing states in the United States. It has the fourth largest natural gas reserves, and crude oil production in the region has more than doubled since 2010 due to new technologies such as directional drilling and hydraulic fracturing (commonly known as fracking) (U.S. EIA 2019). Between 2007 and 2013, crude oil production in Colorado rose by $146 \%$ and gas production rose by $38 \%$ (Heikkila et al. 2014). Many of the drilling activities take place on Forest Service and Bureau of Land Management (BLM) lands, which make up $36 \%$ of the land area in Colorado (Congressional Research Service 2020).

Currently, oil and gas development on federal lands is governed by a constellation of agencies and organizations that are structured around, and adhere to, formal institutional arrangements such as laws and ordinances that determine when and where oil and gas exploration can occur. The Bureau of Land Management and the U.S. Forest Service are central to the oversight of oil and gas development on federal lands. The Mineral Leasing Act of 1920 and the amended Mineral Leasing Act for Acquired Lands of 1947 gave the Bureau of Land Management the "responsibility for oil and gas leasing on about 564 million acres [228 million hectares] of BLM, national forest, and other Federal lands, as well as State and private surface lands where mineral rights have been retained by the Federal Government" (United States Department of the Interior 2020). The U.S. Forest Service has the authority to decide whether or not the lands under its domain could be leased for oil and gas development (Federal Onshore Oil and Gas Leasing Reform Act of 1987). Currently, the U.S. Forest Service "manages access to, and development of, federal oil and natural gas resources on approximately one-third of the over 150 national forests and grasslands" (United States Department of Agriculture 2020). In other words, the Bureau of Land Management is responsible for leasing the resources (oil and gas) and administering the permits; the U.S. Forest Service is responsible for managing the surface of the lands where the resources are located. By law, the U.S. Forest Service has the authority to regulate ancillary but fundamental activities such as road construction and the installation and operation of drilling pads that would cause surface disturbances.

To identify mismatches in unconventional oil and gas development on federal lands and to understand the role of community-based organizations in bridging scale mismatches, we focused our study on an area of western Colorado where oil and gas production is a hotly contested issue and where multiple community-based organizations exist. We adopted an indepth case study approach as the most suitable way to understand new or emerging phenomena (Yin 2009, Marshall and Rossman 2010). ${ }^{[1]}$ We combined a review of relevant documents related to unconventional oil and gas development in the study area with semistructured interviews with key stakeholders. Relevant documents included those put forth by federal agencies (e.g., U. S. Forest Service, Bureau of Land Management) as well as newspaper articles and websites. The information retrieved via secondary sources was then complemented by 21 semistructured interviews with key informants. The informants were identified using a snowball sampling technique, where we asked the interviewees to think of the names of others who were involved in the lease cancellation process. The snowball sampling process started from interviews with key members of the Thompson Divide Coalition, an organization that was formed with the objective of cancelling leases located in the southern region of the White River National Forest. The southern region of the forest is referred to by many locals as the "Thompson Divide." The 21 interviews represented the following six key stakeholder groups: (1) congressional staff who worked on the lease cancellation process, (2) key organizers of the campaign to cancel the leases, (3) recreationists, (4) local business owners, (5) county commissioners, and (6) federal land managers. Interview questions focused on eliciting narratives related to the lease cancellation process. Interviews were recorded if participants were comfortable with being recorded; if not, detailed notes were taken during the interviews and were sent back to the respondents to make sure the notes accurately represented their ideas. We examined data collected from the interviews and the document review, and engaged in an iterative process of coding to identify themes related to scale and scalar mismatches (Saldana 2015). The interview guide is provided in Appendix I.

\section{Case study background: timeline and actors}

Our case study was located in the White River National Forest, a 2.3 million-acre $(930,779$-hectare) forest that straddles multiple counties in the Western Slope region of Colorado (Fig. 1). The diverse economy of this region relies heavily on federal lands, and ranges from ranching and agriculture to recreation and mining. While oil and gas leasing has been ongoing in the forest, the development of new technologies such as hydraulic fracturing has increased the potential for drilling, and oil and gas now plays a 
Fig. 1. Study area. (Credit: Francis Russell)

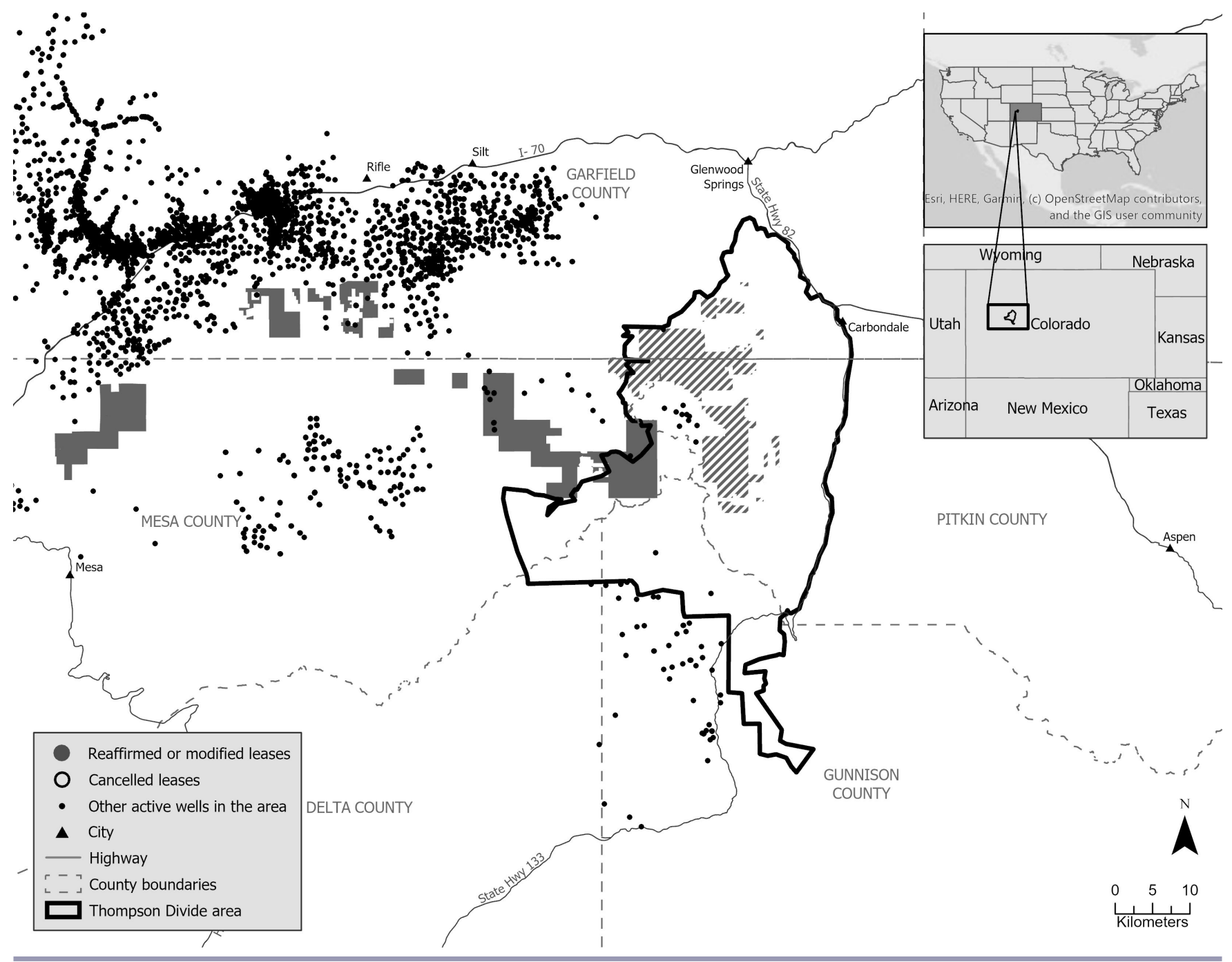

dominant role in the economy of the region. The economies of the key counties adjacent to the White River National Forest (Pitkin, Garfield, and Mesa) were historically based on the boom and bust cycle of resource extraction (e.g., coal). However, over the past decades, counties have diverged in their development pathways: Pitkin County has moved toward an amenity-based economy fueled by upscale ski areas, such as Vail Resorts, and claims to be the highest per capita income county in Colorado, while Mesa County continues to be focused on the resource extraction economy, with its primary tax base stemming from the oil and gas industry. Garfield County, located in between Mesa and Pitkin Counties, has the second highest producing oil and gas wells in the state of Colorado and an expanding recreation economy.

In 2004, Wilderness Workshop, a wilderness advocacy organization located in Garfield County, wanted to protect areas of the White River National Forest under the Wilderness Act. The organization learned that the area it wanted to designate as wilderness had existing leases within the area. While there was not strong support for a wilderness designation, the support against oil and gas expansion was strong enough that community members formed the Thompson Divide Coalition to "secure permanent protection from oil and gas development of federal lands in the Thompson Divide Area" (Thompson Divide Coalition 2020).

In 2015, the Forest Supervisor published a Record of Decision that closed the Thompson Divide area to leasing. Ultimately, the Forest Supervisor changed the area of land available for leasing from 411,475 acres $(166,518$ hectares) to 194,123 acres $(78,559$ hectares), a decision that would stay in effect for 20 years. Shortly afterward, the Bureau of Land Management canceled 25 of the 65 leases and reimbursed the oil and gas companies for the leases.

\section{RESULTS}

Results from the interviews and document review revealed how community-based organizations addressed different types of scale mismatches and how they played a role in bridging scale mismatches present in unconventional oil and gas development on Forest Service land in western Colorado. 


\section{Time frames for decision-making mismatched with the values of the community and technological advances in the oil and gas industry}

In 2002, when the White River National Forest was revisiting its National Forest Land and Resource Management Plan, there was little concern about the leases in the southern region of the forest; they were in remote and difficult-to-access terrain and "no one thought it would be developed. They [oil and gas companies] just wanted them to have them...they were speculative leases" (Small business owner 1). However, as technology made those reserves easier to access, the public grew concerned and argued that the Forest Plan needed to be updated to limit oil and gas activity in the area given its potential adverse impacts on the recreation economy in the region.

With respect to the oil and gas leases in the Thompson Divide area, temporal mismatches arise from the time lag between the decision to sell oil and gas permits and the changes in values and beliefs of local communities. In addition, the development of new technology that increases the profitability of oil and gas exploration created specific challenges. Drilling leases, once issued, can be held for long periods and are extremely difficult to revoke, even if management priorities change. Oil and gas companies invest money in exploration and set up infrastructure at the drilling pads. Once drilling starts, "there is no way we [the Forest Service] could've stopped the drilling. No way" (Forest Service employee).

However, the Thompson Divide Coalition was still able to advocate for the cancellation of existing leases that had not yet been developed. It did so by commissioning a report that showcased the trends in the local economy and documented the monetary and nonmonetary benefits the Thompson Divide region provided. The report highlighted the importance of agriculture and the tourism economy, how the sectors supported more than half the jobs in the area, and how oil and gas would undermine the long-term sustainability of the economy. The Thompson Divide Coalition focused on shifting the discourse from one focused on the short-term benefits of oil and gas exploration to one focused on the long-term benefits the area provides to the community. In addition, the Thompson Divide Coalition emphasized that many of the leases were speculative, and encouraged the Forest Supervisor to "concentrate future lease sales in areas where we already have development" (Forest Service employee). In 2015, the almost-decade-long battle to limit oil and gas activity in the Thompson Divide region culminated in the Forest Supervisor closing the area to leasing. Of note is that the decision is not permanent and is in effect for only the next 20 years; the Forest Supervisor believes that this decision "strikes a balance best meeting the needs of the immediate future" (United States Forest Service 2015:8).

\section{Scale of management institutions mismatched with the scale of the geographical area}

The institutions set up to govern oil and gas on the White River National Forest are for a large geographical area, and the assessments undertaken by the Forest Service did not account for the unique characteristics the Thompson Divide region offered. In addition, even though drilling activity can take place on a relatively small spatial area, the ramifications of accessing the drill pad can cause significant spatial disturbance due to the network of roads, pipelines, gravel pits, and staging areas needed (United States Forest Service 2015). One business owner stated, "our business wouldn't be viable with 150 trucks rattling the windows" (Small business owner 2). To better assess the environmental impacts oil and gas development would have on the local community, the Thompson Divide Coalition asked the Roaring Fork Conservancy, a local watershed advocacy group, to draft a report focused on environmental health and provide reliable, scientific information on watershed quality in the area.

The Thompson Divide Coalition also recognized the importance of focusing on a relatively smaller geographical area when addressing oil and gas development. Instead of addressing oil and gas development in the entire forest, the Coalition chose to focus on a smaller area and to use the phrase "Thompson Divide" to convey its targeted geographical focus. Several of the interviewees reflected in interviews that "Thompson Divide" was an appropriate name because it was familiar and well-known to many stakeholders, saying "a few of us who were trying to start the coalition decided to call it that [Thompson Divide]" (Rancher 1). Unlike towns, counties, or districts, the Thompson Divide did not have clearly drawn boundaries; Forest Service and Bureau of Land Management maps do not show that there is an area with that name. Rather, interviews revealed that the name "Thompson Divide" was created at an initial meeting where "we were all just sitting around trying to figure out what to call the area" (Rancher 2). This name allowed the Thompson Divide Coalition to build alliances with all the relevant stakeholders affected by unconventional oil and gas development in the area; it allowed them to "communicate with a broader audience" (Thompson Divide Coalition member 1) and appeal to multiple values. As a result of this strategy, "it was not the usual narrative of the greens are on one side, prodevelopment people on the other and we're going to fight this out...it was a very collective and broad-based group that all had the same concerns" (Forest Service employee).

Another type of spatial mismatch that needed to be overcome was the fact that the geographical area of the Thompson Divide region crossed multiple jurisdictional boundaries. While the leases spanned 40 miles $(64 \mathrm{~km})$ from east to west, the area crossed five county boundaries (Fig. 1). The counties have different priorities: Mesa and Delta Counties did not want the leases canceled, given their reliance on oil and gas, whereas Gunnison, Pitkin, and Garfield Counties were more receptive to lease cancellation: "we feel it needs to be developed but only in a safe and effective manner" (Garfield County Commissioner). The Forest Supervisor had to balance counties' different priorities when deciding whether or not to cancel the leases. To address the mismatch, the Thompson Divide Coalition shifted the boundaries of the area it sought to protect so the boundaries would reflect each county's unique desires. Shifting the boundaries was necessary to get support from Gunnison's county commissioners and to lessen the resistance from oil and gas companies. By staying flexible on boundaries, they were able to "achieve a balance that meets the needs of stakeholders on both sides of the table" (Gunnison County Commissioner).

\section{Scale of social organization mismatched with the scale at which} management activities take place

The Forest Supervisor ultimately makes the decision about whether or not to cancel the leases and close the area to future 
leases. That decision would require amendments to the Forest Plan. ${ }^{[2]}$ In this case study, the Forest Supervisor wanted to make decisions that would reflect the diverse interests of the community as well as the agency's mission to manage the land for current and future generations. Given that the leases were on federal land, canceling the leases and ensuring that the area would be closed to future leasing required broad support.

However, initially the overall process of canceling the leases was characterized by "a lot of known conflicts" (Wilderness Workshop employee) and opposition to the project by different stakeholders, such as "a vocal mountain bike community...the active snowmobile club with a lot of groomed trails, the ranchers who rely on the permits" (Rancher 1). The lease cancellation provided an opening for a conversation about the different ways the local community valued the Thompson Divide region. To get enough support for lease cancellation, the Thompson Divide Coalition had to work with multiple stakeholders to send a unified message to the Forest Supervisor. Overcoming the mismatch between the scale of social organization and the scale at which management activities took place required the Thompson Divide Coalition to galvanize support at the local level and identify stakeholders at a national level who would bring additional expertise on how to navigate bureaucratic processes.

Creating a common vision was important because "each and every one of them [the stakeholders] has a personal issue, but there's also a group issue - no one wants drilling in the area. Certain ones that just want no trespassing, others don't want to share the grass with other people, some say 'we don't want anyone to drive up here.'...There's a conglomerate of issues" (Garfield County Commissioner). While opinions varied on the extent to which the area should be protected (e.g., whether or not motorized recreation should be allowed), there was a shared vision on the importance of the area. "If you have Board of Directors who are walking the wilderness line, you alienate ranchers and recreationists. You need a diverse Board with no big egos, egos get in the way of progress, so we were very conscious of who was part of the Board" (Rancher 2).

Comments such as "we [Thompson Divide Coalition] were really clear with Wilderness Workshop that we were not under their direction, we were not fighting your battle, we're not going to go after the wilderness, we're not going to speak about hidden gems...we were here to stop oil and gas development. Don't muddy the waters with other agendas, because then you get distracted, and it's easier for the opposition to come in and say you're not here for oil and gas, you're here for wilderness" (Rancher 2) highlight the importance of keeping a single objective and focus when building consensus. To gain support, the Thompson Divide Coalition was specific about not stopping oil and gas everywhere; it focused instead on how some areasspecifically the Thompson Divide region-were more important than other areas because it had "unique singular characteristics" (Thompson Divide Coalition member 2). Members of the Thompson Divide Coalition said they did not want to isolate others in the community, and the Forest Supervisor also chose to emphasize the "human experience in a landscape, the local knowledge, culture, and folklore" (United States Forest Service 2015:6) when discussing the final decision.

Focusing on the characteristics of the Thompson Divide that everyone could agree on created a space for dialogue and action.
As one rancher said, "When you go in with all your environmental groups and the cattleman association, you come into your senator's office and say 'Sierra Club and other environmental groups and cattleman association both want you to do this.' First, he falls over, and then he asks you what you need and says he's going to sign on to it. I would say the strength of the Coalition is the multiple interests that are represented" (Rancher 1). The Thompson Divide Coalition also encouraged conversation among "strange bedfellows" (Thompson Divide Coalition member 2) through town hall meetings, roundtables, and numerous pancake breakfasts with county commissioners; putting aside differences among multiple users, such as "the enviros and low impact users, motorized communities that are always under siege" (Rancher 2) was the quickest way to "get it all done and fight" (Rancher 2).

In addition, the Thompson Divide Coalition encouraged the formation of numerous other place-based groups to show support for the lease cancellation. For example, organizations such as the Roaring Fork Mountain Bike Association, North Thompson Cattleman Association, Coal Basin Cattleman Association, and Sportsmen for the Thompson Divide asked people who were interested in advocating for lease cancellation to join the group; one interviewee said these groups were "cobbled together" (Mountain Bike Association member) so there would be the appearance of stronger support for the lease cancellation. National groups-Sierra Club, Audubon Society, Wilderness Society, and Trout Unlimited-also signed on as groups that would support the lease cancellation. These more regional and national groups were important because they were "speaking to a constituency....and [could] speak to western communities that were key part of the community" (Wilderness Workshop employee). The national organizations were important for "publicizing issues and bringing a large volume of comments"[3] (Forest Service employee) to the Forest Supervisor.

\section{DISCUSSION}

In the following discussion, we place our results in a broader context of the role of community-based organizations in federal land management. We discuss how federal agencies and community-based organizations interact with larger systems of local, regional, and federal governance to create opportunities for local communities to meaningfully participate in hierarchical, top-down structures.

\section{Aligning actors and objectives to maximize scale framing}

The Thompson Divide Coalition recognized the importance of building consensus at a local level and then framing its mission to cancel leases as a national issue as well. Building this consensus required creative framing and discursive strategies. In this case study, the Thompson Divide Coalition framed unconventional oil and gas development as an activity that affects pristine wilderness as well as hunting and outdoor recreation. This narrative increased support from national organizations that shared similar values and could provide additional support to the cause by asking their membership base to write letters to the Forest Supervisor.

Our results suggest that bridging organizations that want to effectively connect diverse stakeholders need to construct narratives that frame the problem differently for different stakeholders while maintaining a common underlying vision and 
purpose. This concept of "scale frames"-where actors "construct meaningful (and actionable) linkages between the scale at which a social problem is experienced and the scale(s) at which it could be politically addressed or resolved" (Kurtz 2003:894) — was necessary to achieve the end result of lease cancellation. Similar strategies have been used in the past to promote collaboration across scales and achieve conservation objectives (Wyborn and Bixler 2013). Our case study shows that this strategy can also be applied to smaller geographical areas and to a sector with clear economic and power asymmetries such as the oil and gas industry.

Our results confirm that appropriate narratives and adoption of clear and tailored framing can also help in overcoming issues of institutional fit (Wyborn and Bixler 2013). By framing the lease cancellation as something that would provide significant longterm benefits to the local communities and provide a wide suite of social, cultural, and ecological benefits, the Thompson Divide Coalition aligned its objective-lease cancellation - within the Forest Service's scope of work. The Coalition's narratives fit in with the Forest Service's mandate to ensure that activities in forests are compatible with its mission to manage resources for generations to come while also striking a balance with "best meeting the needs for the immediate future" (United States Forest Service 2015:8).

In addition, our results confirm that tight social networks are necessary for successful collaboration (Wondolleck and Yaffee 2000, Armitage et al. 2008). While some studies suggest that longstanding community-based organizations with close ties to local communities play a significant role (Danks 2009), the formation of a new community-based organization-specifically the Thompson Divide Coalition - to address this issue was beneficial because its single mission was detached from the agenda and the reputation of the other organizations in the area. As a relatively new actor in the community, the Thompson Divide Coalition was receptive to collaborating with others but never lost focus on the process or the outcomes, thereby contributing to its success (Yaffee and Wondolleck 2000). However, our results also show that a single actor is not enough. A variety of actors - not just numerically but also in terms of interests and skills - is necessary (Tindall et al. 2012).

\section{Engaging in institutional work to foster transition toward adaptive collaborative governance}

Adaptive collaborative governance is an approach where groups intentionally learn and adapt their decision to local conditions; this approach focuses on the inclusion of stakeholders in the development of both the decision and the outcomes (Olsson et al. 2006, Plummer et al. 2013, McDougall and Bandjade 2015). In this context, the Thompson Divide Coalition advocated for broader community participation and identified ways existing institutions and governance mechanisms can create space where local communities' voices can be heard. Further, it provided necessary information and promoted change (attributes of adaptive governance per se [see Dietz et al. 2003]). Hence, the Thompson Divide Coalition was able to network and collaborate to bridge scale mismatches. It used existing institutions to facilitate the likelihood that centralized organizations can still make decisions that reflect the values and beliefs of the local community. Even though previous research suggests that centralized organizations have a difficult time overcoming scalerelated mismatches (Cumming et al. 2006), our research shows that community-based organizations can serve as catalysts for centralized organizations such as the Forest Service to minimize issues of scale and maximize fit.

Recently, scholars have highlighted the potential for adaptive and collaborative governance to reduce scalar mismatches pertaining to federal land management (Schultz et al. 2019). In theory, adaptive collaborative governance allows for collective action and the creation of rules and institutions that are congruent with local context (Cosens et al. 2018). This congruence between local conditions and rules (also one of Ostrom's institutional design principles) is a key attribute for successfully managing resources that are rivalrous but not excludable (Ostrom 1990, Baggio et al. 2016). In the context of community-based organizations and their impact on federal landscapes, adaptive collaborative governance has the potential to allow for policies that match the desires of local communities and reduce conflict (Brunner et al. 2005), as well as being able to bridge potential scale mismatches (Ansell and Gash 2008).

The Coalition's actions underscore the importance of bridging organizations in the transition toward adaptive governance. This transition toward adaptive collaborative governance requires community-based organizations to engage in "institutional work," where organizations "create, maintain and disrupt" institutions (Lawrence et al. 2009:216). The Thompson Divide Coalition served as an umbrella organization that allowed communities to collectively work together to deconstruct and interpret the rules laid out in the National Environmental Policy Act, an Act that requires federal agencies to assess environmental impacts of potential actions prior to making a final management decision. Further, undertaking institutional work requires different organizations to bring their unique capacities across the local, regional, and national scales; organizations need to look "out" as well as "in" if they want to achieve their objectives (McDermott et al. 2011). However, uneven power among and within communities remains a significant issue, and certain communities may have more power to craft narratives that serve their interests (Ingalls et al. 2019). Organizations need to pay particular attention to these power dynamics and examine how their institutional work to ensure that communities, even with values different from their mission, can be represented and included in the process.

In the context of the difficult-to-change paradigm of federal land management, our study suggests that recognizing the power of bridging organizations can lead to the creation of more flexible governance networks and provide an entry point for fostering resilient social-ecological systems (Folke 2006, Vatn and Vedeld 2012). Our results also suggest that creating and maintaining flexible governance networks can increase the likelihood that community-based organizations can conduct their institutional work.

\section{Landscapes as boundary objects and forming identities that superseded political identities}

Our study demonstrates that community-based organizations can facilitate the transformation of landscapes into boundary objects upon which people can attach meaning (Star 1989, 2010). The relatively smaller spatial area that the Thompson Divide Coalition 
focused on allowed it to focus on one particular landscape and craft a narrative about it; the Coalition was successful in galvanizing the local community because it created a common vision, had a clear message, and was easily recognizable by using a single name.

Previous research has suggested that a physical environment can contribute to a sense of place (Stedman 2003). Our study shows that specific geographical boundaries can be less important. Rather, it is the idea of a landscape, and the values it holds, that can mobilize a community. The emphasis on ideas and values of a landscape aligns with past studies that have found that people can attach a range of meanings to landscapes and how involvement and sense of attachment to a landscape can motivate people to protect it (Enqvist et al. 2019, Murphy et al. 2019). Additionally, our study suggests that appealing to multiple identities and allowing people to put their own meaning onto a place-however vague the boundaries or the notions associated with it are - can be a possible solution to garnering support and building consensus on contentious issues. While place-based modes of collaboration are common, they are not always successful (Cheng et al. 2015). Our results suggest that fostering a common sense of place and a sense stewardship can increase the likelihood of successful collaboration on contentious issues. In addition, fostering this sense of place can transcend political boundaries (Mayer and Shelley 2018). Even though building consensus among diverse stakeholders who function across different spatial and temporal scales is a challenge (Heikkila and Gerlak 2005, Cronin and Weingart 2007), focusing on a strong sense of place while maintaining flexibility in physical boundaries can be key in achieving objectives.

\section{CONCLUSIONS}

The rural American West continues to face a multitude of challenges related to land management. Recognizing the scale mismatches and ways to overcome them is key to ensuring the social-ecological resiliency of federal lands. Despite the importance of oil and gas on federal lands, relatively little is known about the mismatches that affect management practices. Our research shows how community-based organizations can bridge different spatial and temporal scales and affect the trajectory of unconventional oil and gas development. In western Colorado, community-based organizations were able to connect diverse stakeholders and create a shared vision that captured a diversity of viewpoints. This process closed the representational gaps (sensu Cronin and Weingart 2007, 2019) and addressed some of the mismatches within unconventional oil and gas development. Our results demonstrate the importance of clear narratives that are adaptable but also possess an underlying clear vision of the future (Milkoreit 2017). In addition, our study shows that organizations need to have the resources to assess the risks and benefits related the system feedbacks, and they need to communicate effectively to diverse stakeholder groups that may hold different agendas and core values/beliefs (see also Baggio et al. 2019, Freeman et al. 2020). Focusing on giving meaning to landscapes so they can be transformed into boundary objects that hold different values for different stakeholders is a viable way to move forward. Finally, we also reiterate the importance of maintaining adaptable and flexible governance networks for achieving specific objectives (Bierman et al. 2017); these networks are key to reducing scale mismatches and increasing the likelihood of institutional fit on federal lands.
${ }^{[1]}$ The authors do not have a specific stance for or against oil and gas exploration on federal lands. Unconventional oil and gas development contributes significantly to the economic base of communities in the area. However, existing research shows that it also compromises the ecological resiliency of the landscape. We are ultimately interested in how community-based organizations bridge mismatches in scale and engage with a hierarchical governance system.

${ }^{[2]}$ The decision has to be in accordance with the Forest Plan, which can be revisited or added to if necessary.

[3] "During the comment period of the National Environmental Policy Act process, the White River National Forest received 185 unique letters and three different form letters that were submitted approximately 12,000 times. [The]...total number of unique comments from all letter sources was 667" (United States Forest Service 2015:13). The quantity of letters matters to a certain extent when determining the final outcome (canceling the lease or not canceling the lease). While the Bureau of Land Management and U.S. Forest Service do not make a decision based on sheer number of letters, they do look at the letters to see if there are substantial issues that need to be addressed in the analysis.

Responses to this article can be read online at: https://www.ecologyandsociety.org/issues/responses. php/12029

\section{Acknowledgments:}

The first author thanks the interviewees for graciously sharing their time and insight, and the generous financial support from the Colorado College Social Science Executive Council.

\section{Data Availability:}

The datalcode that support the findings of this study are available on request from the corresponding author, JL. The datalcode are not publicly available because they contain information that could compromise the privacy of research participants.

\section{LITERATURE CITED}

Abrams, J., E. J. Davis, and C. Moseley. 2015. Community-based organizations and institutional work in the remote rural West. Review of Policy Research 32(6):675-698. https://doi.org/10.1111/ ropr. 12148

Ager, A. A., C. R. Evers, M. A. Day, H. K. Preisler, A. M. G. Barros, and M. Nielsen-Pincus. 2017. Network analysis of wildfire transmission and implications for risk governance. $P L o S$ ONE 12(3):e0172867. https://doi.org/10.1371/journal.pone.0172867

Ansell, C., and A. Gash. 2008. Collaborative governance in theory and practice. Journal of Public Administration Research and Theory 18(4):543-571. https://doi.org/10.1093/jopart/mum032

Armitage, D. 2005. Adaptive capacity and community-based natural resource management. Environmental Management 35 (6):703-715. https://doi.org/10.1007/s00267-004-0076-Z 
Armitage, D. R., R. Plummer, F. Berkes, R. I. Arthur, A. T. Charles, I. J. Davidson-Hunt, A. P. Diduck, N. C. Doubleday, D. S. Johnson, and M. Marschke. 2008. Adaptive co-management for social-ecological complexity. Frontiers in Ecology and the Environment 7(2):95-102. https://doi.org/10.1890/070089

Baggio, J. A., A. J. Barnett, I. Perez-Ibara, U. Brady, E. Ratajczyk, N. Rollins, C. Rubiños, H. C. Shin, D. J. Yu, R. Aggarwal, J. M. Anderies, and M. A. Janssen. 2016. Explaining success and failure in the commons: the configural nature of Ostrom's institutional design principles. International Journal of the Commons 10(2):417. https://doi.org/10.18352/ijc.634

Baggio, J. A., J. Freeman, T. R. Coyle, T. T. Nguyen, D. Hancock, K. E. Elpers, S. Nabity, H. J. F. Dengah, and D. Pillow. 2019. The importance of cognitive diversity for sustaining the commons. Nature Communications 10(1):875. https://doi.org/10.1038/ $\underline{\text { s41467-019-08549-8 }}$

Biermann, F., N. Kanie, and R. E. Kim. 2017. Global governance by goal-setting: the novel approach of the UN Sustainable Development Goals. Current Opinion in Environmental Sustainability 26-27:26-31. https://doi.org/10.1016/j.cosust.2017.01.010

Bodin, Ö., and D. Nohrstedt. 2016. Formation and performance of collaborative disaster management networks: evidence from a Swedish wildfire response. Global Environmental Change 41:183-194. https://doi.org/10.1016/j.gloenvcha.2016.10.004

Brunner, R. D., T. A. Steelman, L. Coe-Juell, C. M. Cromley, C. M. Edwards, and D. W. Tucker. 2005. Adaptive governance, integrating science, policy and decision making. Columbia University Press, New York, New York, USA.

Cash, D. W., W. Adger, F. Berkes, P. Garden, L. Lebel, P. Olsson, L. Pritchard, and O. Young. 2006. Scale and cross-scale dynamics: governance and information in a multilevel world. Ecology and Society 11(2):8. [online] URL: http://www.ecologyandsociety. org/vol11/iss $2 /$ art $8 /$

Cash, D. W., and S.C. Moser. 2000. Linking global and local scales: designing dynamic assessment and management processes. Global Environmental Change 10(2):109-120.

Charnley, S., R. J. McLain, and E. M. Donoghue. 2008. Forest management policy, amenity migration, and community wellbeing in the American West: reflections from the Northwest Forest Plan. Human Ecology 36:743-761. https://doi.org/10.1007/ s10745-008-9192-3

Cheng, A. S., A. K. Gerlak, L. Dale, and K. Mattor. 2015. Examining the adaptability of collaborative governance associated with publicly managed ecosystems over time: insights from the Front Range Roundtable, Colorado, USA. Ecology and Society 20(1):35. https://doi.org/10.5751/ES-07187-200135

Clark, C. E., A. J. Burnham, C. B. Harto, and R. M. Horner. 2012. Introduction: the technology and policy of hydraulic fracturing and potential environmental impacts of shale gas development. Environmental Practice 14(4):249-261. https://doi.org/10.1017/ $\underline{\mathrm{S} 1466046612000415}$

Clark, W. C., T. P. Tomich, M. van Noordwijk, D. Guston, D. Catacutan, N. M. Dickson, and E. McNie. 2016a. Boundary work for sustainable development: natural resource management at the
Consultative Group on International Agricultural Research (CGIAR). Proceedings of the National Academy of Sciences of the United States of America 113(17):4615-4622. https://doi. org/10.1073/pnas.0900231108

Clark, W. C., L. Van Kerkhoff, L. Lebel, and G. C. Gallopin. 2016b. Crafting usable knowledge for sustainable development. Proceedings of the National Academy of Sciences of the United States of America 113(17):4570-4578.

Congressional Research Service. 2020. Federal land ownership: overview and data. https://fas.org/sgp/crs/misc/R42346.pdf

Cosens, B. A., L. Gunderson, and B. C. Chaffin. 2018. Introduction to the Special Feature Practicing Panarchy: assessing legal flexibility, ecological resilience, and adaptive governance in regional water systems experiencing rapid environmental change. Ecology and Society 23(1):4. https://doi. org/10.5751/ES-09524-230104

Cronin, M. A., and L. R. Weingart. 2007. Representational gaps, information processing, and conflict in functionally diverse teams. Academy of Management Review 32(3):761-773. https://doi. org/10.5465/amr.2007.25275511

Cronin, M. A., and L. R. Weingart. 2019. Conflict across representational gaps: threats to and opportunities for improved communication. Proceedings of the National Academy of Sciences of the United States of America 116(16):7642-7649. https://doi. org/10.1073/pnas.1805866116

Cumming, G. S., D. H. M. Cumming, and C. L. Redman. 2006. Scale mismatches in social-ecological systems: causes, consequences, and solutions. Ecology and Society 11(1):14. https://doi.org/10.5751/ES-01569-110114

Danks, C. 2009. Benefits of community-based forestry in the US: lessons from a demonstration programme. International Forestry Review 11(2):171-185. https://doi.org/10.1505/ifor.11.2.171

Dietz, T., E. Ostrom, and P. C. Stern. 2003. The struggle to govern the commons. Science 302(5652):1907-1912. https://doi. org/10.1126/science.1091015

Enqvist, J. P., L. K. Campbell, R. C. Stedman, and E. S. Svendsen. 2019. Place meanings on the urban waterfront: a typology of stewardships. Sustainability Science 14:589-605. https://doi. org/10.1007/s11625-019-00660-5

Epstein, G., J. Pittman, S. M. Alexander, S. Berdej, T. Dyck, U. Kreitmair, K. J. Rathwell, S. Villamayor-Tomas, J. Vogt, and D. Armitage. 2015. Institutional fit and the sustainability of socialecological systems. Current Opinion in Environmental Sustainability 14:34-40. https://doi.org/10.1016/j.cosust.2015.03.005

Fischer, A. P. 2018. Forest landscapes as social-ecological systems and implications for management. Landscape and Urban Planning 177:138-147. https://doi.org/10.1016/j.landurbplan.2018.05.001

Folke, C. 2006. Resilience: the emergence of a perspective for social-ecological systems analyses. Global Environmental Change 16(3):253-267. https://doi.org/10.1016/j.gloenvcha.2006.04.002

Folke, C., L. Pritchard Jr., F. Berkes, J. Colding, and U. Svedin. 2007. The problem of fit between ecosystems and institutions: ten years later. Ecology and Society 12(1):30. https://doi.org/10.5751/ ES-02064-120130 
Freeman, J., J. A. Baggio, and T. R. Coyle. 2020. Social and general intelligence improves collective action in a common pool resource system. Proceedings of the National Academy of Sciences of the United States of America 117(14):7712-7718. https://doi. org/10.1073/pnas.1915824117

Galaz, V., P. Olsson, T. Hahn, C. Folke, and U. Svedin. 2008. The problem of fit among biophysical systems, environmental and resource regimes, and broader governance systems: insights and emerging challenges. Pages 147-186 in O. R. Young, L. A. King, and $\mathrm{H}$. Schroeder, editors. Institutions and environmental change: principal findings, applications, and research frontiers. MIT Press, Cambridge, Massachusetts, USA. https://doi.org/10.7551/ mitpress/9780262240574.003.0005

Gibson, C. C., E. Ostrom, and T. K. Ahn. 2000. The concept of scale and the human dimensions of global change: a survey. Ecological Economics 32(2):217-239.

Gruber, J. S. 2010. Key principles of community-based natural resource management: a synthesis and interpretation of identified effective approaches for managing the commons. Environmental Management 45(1):52-66. https://doi.org/10.1007/s00267-008-9235y

Heikkila, T., and A. K. Gerlak. 2005. The formation of largescale collaborative resource management institutions: clarifying the roles of stakeholders, science, and institutions. Policy Studies Journal 33(4):583-612. https://doi.org/10.1111/j.1541-0072.2005.00134. $\underline{\mathrm{X}}$

Heikkila, T., J. J. Pierce, S. Gallaher, J. Kagan, D. A. Crow, and C. M. Weible. 2014. Understanding a period of policy change: the case of hydraulic fracturing disclosure policy in Colorado. Review of Policy Research 31(2):65-87.

Ingalls, M. L., A. Kohout, and R. C. Stedman. 2019. When places collide: power, conflict and meaning at Malheur. Sustainability Science 14:625-638. https://doi.org/10.1007/s11625-019-00689-6

Kurtz, H. E. 2003. Scale frames and counter-scale frames: constructing the problem of environmental injustice. Political Geography 22(8):887-916. https://doi.org/10.1016/j.polgeo.2003.09.001

Lawrence, T. B., R. Suddaby, and B. Leca, editors. 2009. Institutional work: actors and agency in institutional studies of organizations. Cambridge University Press, New York, New York, USA. https://doi.org/10.1017/CBO9780511596605

Lebel, L., E. Nikitina, C. Pahl-Wostl, and C. Knieper. 2013. Institutional fit and river basin governance: a new approach using multiple composite measures. Ecology and Society 18(1):1. https:// doi.org/10.5751/ES-05097-180101

Marshall, C., and G. B. Rossman. 2010. Designing qualitative research. Fifth edition. SAGE Publications.

Mayer, A., and T. O. Shelley. 2018. The dual importance of political identity in environmental governance: the case of oil and gas policy in Colorado. Society \& Natural Resources 31 (11):1230-1247. https://doi.org/10.1080/08941920.2018.1464235

McDermott, M., M. A. Moote, and C. Danks. 2011. Effective collaboration: overcoming external obstacles. In: F. Dukes, K. Firehock, and J. Birkhoff, editors. Community-based collaboration: bridging socio-ecological research and practice. University of Virginia Press, Charlottesville, Virginia, USA.

McDougall, C., and M. R. Banjade. 2015. Social capital, conflict, and adaptive collaborative governance: exploring the dialectic. Ecology and Society 20(1):44. https://doi.org/10.5751/ES-07071-200144

Milkoreit, M., 2017. Imaginary politics: climate change and making the future. Elementa: Science of the Anthpocene 5:62. https://doi.org/10.1525/elementa.249

Molden, O., J. Abrams, E. J., Davis, and C. Moseley. 2017. Beyond localism: the micropolitics of local legitimacy in a communitybased organization. Journal of Rural Studies 50:60-69.

Murphy, A., J. Enqvist, and M. Tengö. 2019. Place-making to transform urban social-ecological systems: insights from the stewardship of urban lakes in Bangalore, India. Sustainability Science 14:607-623. https://doi.org/10.1007/s11625-019-00664-1

Olsson, P., L. H. Gunderson, S. R. Carpenter, P. Ryan, L. Lebel, C. Folke, and C. S. Holling. 2006. Shooting the rapids: navigating transitions to adaptive governance of social-ecological systems. Ecology and Society 11(1):18. https://doi.org/10.5751/ES-01595-110118

Ostrom, E., 1990. Governing the commons: the evolution of institutions for collective action. Cambridge University Press.

Plummer, R., D. R. Armitage, and R. C. de Loë. 2013. Adaptive co-management and its relationship to environmental governance. Ecology and Society 18(1):21. https://doi. org/10.5751/ES-05383-180121

Saldana, J. 2015. The coding manual for qualitative researchers. Third edition. Sage Publications.

Sayles, J. S., and J. A. Baggio. 2017. Who collaborates and why: assessment and diagnostic of governance network integration for salmon restoration in Puget Sound, USA. Journal of Environmental Management 186:64-78. https://doi.org/10.1016/j. jenvman.2016.09.085

Schoon, M. L., and A. M. York. 2011. Cooperation across boundaries: the role of political entrepreneurs in environmental collaboration. Journal of Natural Resources Policy Research 3 (2):113-123. https://doi.org/10.1080/19390459.2011.557880

Schultz, C. A., T. J. Timberlake, Z. Wurtzebach, K. B. McIntyre, C. Moseley, and H. R. Huber-Stearns. 2019. Policy tools to address scale mismatches: insights from U.S. forest governance. Ecology and Society 24(1):21. https://doi.org/10.5751/ES-10703-240121

Solís, P., J. K. Vanos, and R. E. Forbis. 2017. The decision-making/ accountability spatial incongruence problem for research linking environmental science and policy. Geographical Review 107 (4):680-704. https://doi.org/10.1111/gere.12240

Star, S. L. 1989. Chapter 2 - The structure of ill-structured problems: boundary objects and heterogeneous problem solving. Pages 37-54 in L. Gasser and M. N. Huhns, editors. Distributed Artificial Intelligence. Vol. 2. Pitman, London, UK. https://doi. org/10.1016/B978-1-55860-092-8.50006-X

Star, S. L. 2010. This is not a boundary object: reflections on the origin of a concept. Science, Technology, \& Human Values 35 (5):601-617. https://doi.org/10.1177/0162243910377624 
Stedman, R. C. 2003. Is it really just a social construction?: The contribution of the physical environment to sense of place. Society \& Natural Resources 16(8):671-685. https://doi. org/10.1080/08941920309189

Thompson Divide Coalition. 2020. https://www.savethompsondivide. org/

Tindall, D. B., J. Cormier, and M. Diani. 2012. Network social capital as an outcome of social movement mobilization: using the position generator as an indicator of social network diversity. Social Networks 34(4):387-395. https://doi.org/10.1016/j.

socnet.2011.12.007

United States Congress. 1996. Multiple-Use Sustained-Yield Act of 1960. Amended in 1996: Sec.4 16 U.S.C. 531.

United States Department of Agriculture. 2020. https://www.fs. usda.gov/science-technology/geology/energyminerals/oilandgas

United States Department of the Interior. 2020. BLM lands leasing. https://www.doi.gov/ocl/blm-lands-leasing

United States Energy Information Administration (U.S. EIA). 2019. https://www.eia.gov/

United States Forest Service. 2015. Final Record of Decision: oil and gas leasing on lands administered by the White River National Forest. https://www.fs.usda.gov/Internet/FSE DOCUMENTS/ fseprd485176.pdf

Vatn, A., and P. Vedeld. 2012. Fit, interplay, and scale: a diagnosis. Ecology and Society 17(4):12. https://doi.org/10.5751/ES-05022-170412

Wilson, R. K. 2006. Collaboration in context: rural change and community forestry in the Four Corners. Society \& Natural Resources 19(1):53-70. https://doi.org/10.1080/08941920500323302

Wondolleck, J. M., and S. L. Yaffee. 2000. Making collaboration work: lessons from innovation in natural resource management. Island Press, Washington, D.C., USA.

Wyborn, C., and R. P. Bixler. 2013. Collaboration and nested environmental governance: scale dependency, scale framing, and cross-scale interactions in collaborative conservation. Journal of Environmental Management 123:58-67. https://doi.org/10.1016/j. jenvman.2013.03.014

Yaffee, S. L., and J. M. Wondolleck. 2000. Making collaboration work: lessons from a comprehensive assessment of over 200 wideranging cases of collaboration in environmental management. Conservation in Practice 1(1):17-24.

Yin, R. K. 2009. Case study research: design and methods. Fourth edition. SAGE, Thousand Oaks, California, USA.

York, A. M., and M. L. Schoon. 2011. Collective action on the western range: coping with external and internal threats. International Journal of the Commons 5(2):388-409. https://doi. org/10.18352/ijc. 286

Young, O. R. 2002. The institutional dimensions of environmental change: fit, interplay, and scale. MIT Press. https://doi. org/10.7551/mitpress/3807.001.0001 


\section{Appendix I}

Semi-structured Interview Guide

- Can you please describe the Thompson Divide and what it means to you? For example, what do you value about this landscape? What are ways you use the landscape and what activities do you engage in?

- What did you call the Thompson Divide region/did you refer to it by any other name before it was called the Thompson Divide? If so, what was the name?

- How did you first hear about the leases?

- How long has the Thompson Divide Coalition been around for?

- What groups or organizations were involved in the Thompson Divide Coalition?

- Are you part of any groups or organizations that were involved in the "Save Thompson Divide" initiative?

- Why do you think the leases were successfully cancelled?

- What do you think were key factors in your willingness to work with others on this issue?

- Have you worked with anyone else in your group on this issue before? What about anyone else in the other groups?

- Do you think there was anyone missing at the table during the discussions on lease cancellation?

- How were the different groups and people brought together?

- Was there resistance to lease cancellation from other towns or stakeholders?

- Were there any compromises that you had to make when working on the Thompson Divide issue?

- Did you need to put aside any personal differences to come to the table to collaborate? If so, what differences?

- Did you learn anything new during the lease cancellation process?

- Looking forward, what do you think are future issues or conflicts in the area?

- How do you think these conflicts should be handled?

- Do you think all oil and gas development should be stopped in Colorado?

- How long have you lived in this area for?

- Is there anyone else I should speak to about the lease cancellation in the Thompson Divide region so I can learn more about it?

https://www.ecologyandsociety.org/vol22/iss4/art22/

(Abrams, no list of questions) 